\title{
CRETACEOUS AMMONITES OF WEST AFRICA
}

CRETACEOUS ammonites have long been known
from many parts of West Africa, and some of
the faunas, notably those of Angola, have been the
subject of substantial works. Apart, however, from
descriptions of Turonian and Coniacian faunas from
the Mungo River, comparatively little has been
published about the Cretaceous ammonites of
Nigeria. With the publication, however, of Dr.
R. A. Reyment's "Cretaceous Ammonbidea of
Southern Nigeria and the Southern Cameroons"
we have for the first time a comprehensive mono-
graph of the material from considerable areas of the
country. Dr. Reyment figures about 135 species and
sub-species, many of them new, ranging in age from
Middle Albian to Maestrichtian. He supplies a great
deal of new information of both palæontological and
stratigraphical importance.

The Albian faunas consist mainly of keeled ammonites of the Mortoniceratidae, most of them species already described from Europe, Angola, Zululand or Madagascar. The puzzling genus Neokentroceras, characterized by exceptional tuberculation in the small specimens which alone had been figured, is now shown to have outer whorls like those of many typical members of Mortoniceratinae, in which subfamily it must now be placed. One most surprising discovery was that of a new species of Gyaloceras, an inflated genus of Aconeceratinae, which was previously reported only from Queensland. Like most of the other genera of this subfamily of Oppeliidae, it will probably turn out to have a wide range.

The Nigerian Cenomanian has yielded few ammonites, but the Lower Turonian has produced abundant ammonites of great interest. These include, in particular, a wide range of genera and species representing the burst of radiation from the Acanthoceratidae which characterized the early Turonian.

* Reyment, R. A., "The Cretaceous Ammonoidea of Southern Bulletin No. 25, pp. $112+25$ pl., 46 figs. (Lagos). 208.
Much light is thrown on the relationships of $\operatorname{some}$ genera that have been long but ill known. In addition, there are full descriptions of a number of new genera and sub-genera which fill in gaps in the story of this burst of radiation.

Most of the known forms of the families Tissotiidae and Vascoceratidae (two of the groups derived from Acanthoceratidae) characterize the deposits of the Tethys, the Cretaceous 'Mediterranean' and tropical sea, and it has been impossible to work out any accurate correlation with more northerly Turonian, characterized by other families of ammonites. Special interest therefore lies in Dr. Reyment's discovery, in association with Hoplitoides and Neoptychites, of a few specimens of Watinoceras, a genus which occurs in North America, England, Turkestan and perhaps Japan, and is a valuable stratigraphic indicator.

The later ammonites include an interesting group of Coniacian species, some already described by Solger, and some small and unremarkable Santonian and Maestrichtian faunas.

The author makes a sensible use of subgenera and subspecies. Thus, while he describes all the distinct forms, he avoids that inflation of taxonomic scale which is a common and dangerous tendency on the part, particularly, of those who have to deal with abundant collections of well-preserved fossils. of rapidly evolving groups. No doubt among the reasons for this welcome restraint is the fact that the author is a member of the Geological Survey of Nigeria, in close touch with the field staff, and also has himself collected a large part of the material he describes.

The monograph is very well produced, admirably illustrated both with plates and line-drawings and written with a refreshing clarity and absence of 'ammonite jargon'. It will be of particular value to all who work on the African Cretaceous; but, as already indicated, its interest and importance extend far more widely.
C. W. WRIGHT

\section{PROTEIN METABOLISM, RESPIRATION AND GROWTH* A SYNTHESIS OF RESULTS FROM THE USE OF 19 C-LABELLED SUBSTRATES AND TISSUE CULTURES}

\author{
By Prof. F. C. STEWARD \\ DR. R. G. S. BIDWELL \\ Department of Botany, Cornell University, Ithaca, N.Y. \\ Department of Biology, Queen's University, Kingston, \\ AND
}

Prof. E. W. YEMM

Department of Botany, University of Bristol

\section{Impact of Growth on Fresh Weight, Protein Metabolism and Respiration of Carrot Tissue Explants}

The characteristics of the rapidly dividing cell might reside either in substances that are peculiar to the tissue treated with coconut milk or, alternatively, they may reside more in the intensity of certain processes than in their nature.

$$
\text { (* Continued from p. 734) }
$$

Therefore, one may ask whether the amino-acid composition of the protein in the rapidly dividing cells is different from that of the more resting cells. The amino-acid composition of the entire protein complement in the tissue was determined from the analytical data and the changes that occur with time may also be seen. To reveal the relative molar composition of the protein, the value of 10 was arbitrarily assigned to alanine. The composition of the protein under the different treatments and at 